\title{
Shapes and Mechanisms of Large-Scale Landslides in Japan: Forecasting Analysis from an Inventory (WCoE 2014-2017)
}

\author{
S. Ogita, W. Sagara, Daisuke Higaki, and Research Committee on \\ Elucidating Mechanisms of Large-Scale Landslides
}

\begin{abstract}
Large-scale landslides with widths and lengths of $1 \mathrm{~km}$ or more have been reported in many parts of the world. Occurrences of large-scale landslides have recently tended to increase due to climate change and frequent seismic activity. To conduct research on proper measures for large-scale landslides, elucidation of the occurrence mechanism, for which there are as yet many unclear points, will be required in future. The Japan Landslide Society established a research committee that worked from 2011 to 2014 to elucidate the occurrence mechanisms of large-scale landslides. Analysis of examples of large-scale landslides collected from members of the research committee showed that a volume of moving body larger than $1 \times 10^{6} \mathrm{~m}^{3}$ and a maximum landslide thickness of more than $30 \mathrm{~m}$ are appropriate as the definition of a large-scale landslide. The shape of a large-scale landslide depends on the geology and age of the landslide site, and landslide activity and history affect the symmetry of the shape of a landslide. This paper presents some results of the WCOE (2014-2017) project titled "Emergency response support system for large-scale landslide disasters" by the Japan Landslide Society.
\end{abstract}

\section{Keywords}

Large-scale landslide $\cdot$ Kinematic structure $\cdot$ Landslide topography

\section{Introduction}

Many large-scale landslides, which have brought disaster to lives and properties, have occurred in Japan.

The Jizukiyama landslide (Fig. 1), which occurred in Nagano City in 1985, for example, was $350 \mathrm{~m}$ wide and $280 \mathrm{~m}$ long, with a maximum thickness of $60 \mathrm{~m}$ and a volume of $2.5 \times 10^{6} \mathrm{~m}^{3}$. The landslide buried facilities for

S. Ogita $(\bowtie)$

Okuyama Boring Co. Ltd, 10-39 Shimei-Cho, 013-0046

Yokote-Shi, Akita-Ken, Japan

e-mail: ogita@okuyama.co.jp

W. Sagara

Sabo and Landslide Technical Center, 4-8-21, Kudan-Minami, 102-0074 Chiyoda-Ku, Tokyo, Japan

e-mail: sagara@stc.or.jp the disabled and housing-development apartments, and 26 lives were lost (National Research Institute for Earth Science and Disaster Prevention (NIED) 1986; Shinshu University Research Committee 1986). The Dozan river landslide, which occurred in Yamagata-prefecture in 1996, was $1100 \mathrm{~m}$ wide and $1200 \mathrm{~m}$ long. Its maximum thickness was $180 \mathrm{~m}$, the volume was $1.0 \times 10^{8} \mathrm{~m}^{3}$, and the event caused damage to national roads and the Dozan River.

D. Higaki

Hirosaki University, 3 Bunkyo-Cho, 036-8561 Hirosaki-Shi,

Aomori-Ken, Japan

e-mail: dhigaki@hirosaki-u.ac.jp

Research Committee on Elucidating Mechanisms of Large-Scale Landslides

Japan Landslide Society, 5-26-8 Shinbashi, 105-0004 Minato-Ku, Tokyo, Japan 
The Sumikawa landslide, which occurred in Akita Prefecture in 1997, was $350 \mathrm{~m}$ wide and $650 \mathrm{~m}$ long, with a maximum thickness of $70 \mathrm{~m}$. Some of the moving body, with a volume of $6.0 \times 10^{6} \mathrm{~m}^{3}$ (Furuya and Enokida 2004), partially moved down the river, damaging hot-spring facilities and national roads (Oyagi and Ikeda 1988).

Landslides have occurred at Akadani and Nagadono in the Kii Peninsula in 2011. The volume of the moving body at Akadani is estimated as $9.4 \times 10^{6} \mathrm{~m}^{3}$ (Sakurai 2013); that of Nagadono is $5.0-6.0 \times 10^{6} \mathrm{~m}^{3}$ (Sakurai et al. 2013).

In consideration of the occurrence of large-scale landslides such as those mentioned above, the Japan Landslide Society established the "Research Committee on Elucidating Mechanisms of Large-Scale Landslides" (hereinafter referred to as the Committee) in 2011 to contribute to the prediction of landslide occurrence, the planning of measures, and the development of analysis techniques, with a focus on large-scale landslides.

In the Committee, the main areas of research were the definition of large-scale landslides, characteristics of topography and geology, time-series kinetic structure, effect of groundwater at great depth, shear strength, and stability analysis techniques. A questionnaire was provided to each member to collect examples of large-scale landslides. The instances include ones in which several landslide blocks are aligned (Furuya 2003). Here, 30 instances for which the landslide mechanism has been elucidated are collected to consider the characteristics of landslide kinetic structure and the shapes of landslide sites. For the kinetic structure, the "distribution pattern of displacement, velocity, and acceleration vectors of landslide moving body" defined by Oyagi (2004) is used.

\section{Questionnaire Results}

A total of 30 instances of landslides were collected using the questionnaire: 16 in rocks of Cenozoic age; the other 14 in rocks of Mesozoic and Paleozoic age. The landslides were assigned to groups to summarize the scale and the gradient of landslide sites in the occurrence areas (Fig. 2 and Table 1). Figure 2 shows landslide positions. In Table 1, the maximum landslide width (h), length (L), relative height (rh), gradient of landslide slope $(\theta)$, maximum thickness $(\mathrm{t})$, volume $(\mathrm{v})$, and gradient of sliding surface $(\alpha)$ are listed.

Figure 3 shows the dimension of landslides obtained from the questionaire.
Fig. 1 Full view of the Jizukiyama landslide site (Shinshu University Research Committee 1986)

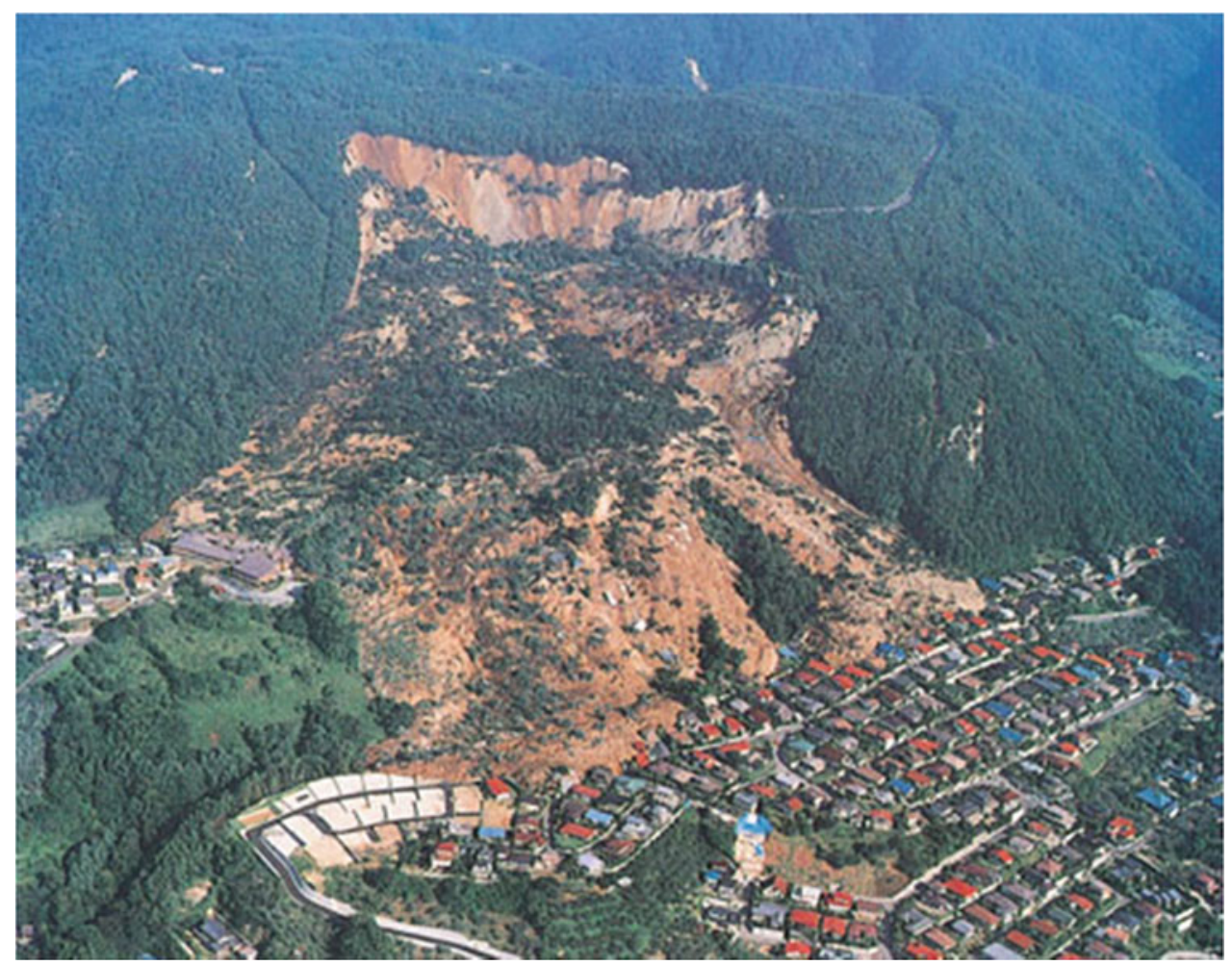


The maximum landslide width ranges from 190 to $2000 \mathrm{~m}$. For landslides with a maximum width of $1000 \mathrm{~m}$ or longer, four instances in Cenozoic strata and one in Mesozoic and Paleozoic rocks are reported (Fig. 3a).

Landslide length ranges from 200 to $2100 \mathrm{~m}$. There are nine instances in Cenozoic rocks and four instances in Mesozoic and Paleozoic strata of landslides that are $1000 \mathrm{~m}$ or more in length (Fig. 3b).

The relative height from the top of a main cliff to the bottom is between 45 and $500 \mathrm{~m}$. For landslides with relative height of less than $100 \mathrm{~m}$, four instances in Cenozoic rocks and one example in Mesozoic and Paleozoic rocks are reported. In contrast, for landslides with a relative height of $300 \mathrm{~m}$ or more, there is one instance in Cenozoic rocks and five in Mesozoic and Paleozoic rocks (Fig. 3c).

The gradient of landslide slope is $6-40^{\circ}$. There are seven examples in Cenozoic rocks and one example in Mesozoic and Paleozoic rocks of landslides with a slope smaller than $10^{\circ}$; in contrast, for slopes $20^{\circ}$ or more, there are three reported instances in Cenozoic rocks and nine in Mesozoic and Paleozoic strata. The examples in Mesozoic and Paleozoic rocks display larger gradients (Fig. 3d).

The maximum landslide thickness is $30-180 \mathrm{~m}$. For landslides with a maximum thickness of $100 \mathrm{~m}$ or more, there are six instances in Cenozoic strata and three in Mesozoic and Paleozoic strata; thus, there are slightly more occurrences in Cenozoic rocks than in older strata (Fig. 3e).

The volume of the moving body is a minimum of $7.0 \times 10^{5} \mathrm{~m}^{3}$ and a maximum of $1.0 \times 10^{8} \mathrm{~m}^{3}$. All 16 instances in Cenozoic rocks and 13 of 14 examples in Mesozoic and Paleozoic rocks have a volume of $1.0 \times 10^{6} \mathrm{~m}^{3}$ or more (Fig. 3f).

The gradient of the sliding surface is the slope immediately under the center of gravity of the landslide section; this parameter varies from $2^{\circ}$ to $31^{\circ}$. There are seven examples in Cenozoic rocks and one example in Mesozoic and Paleozoic

Fig. 2 Instances of landslides obtained by using the questionnaire

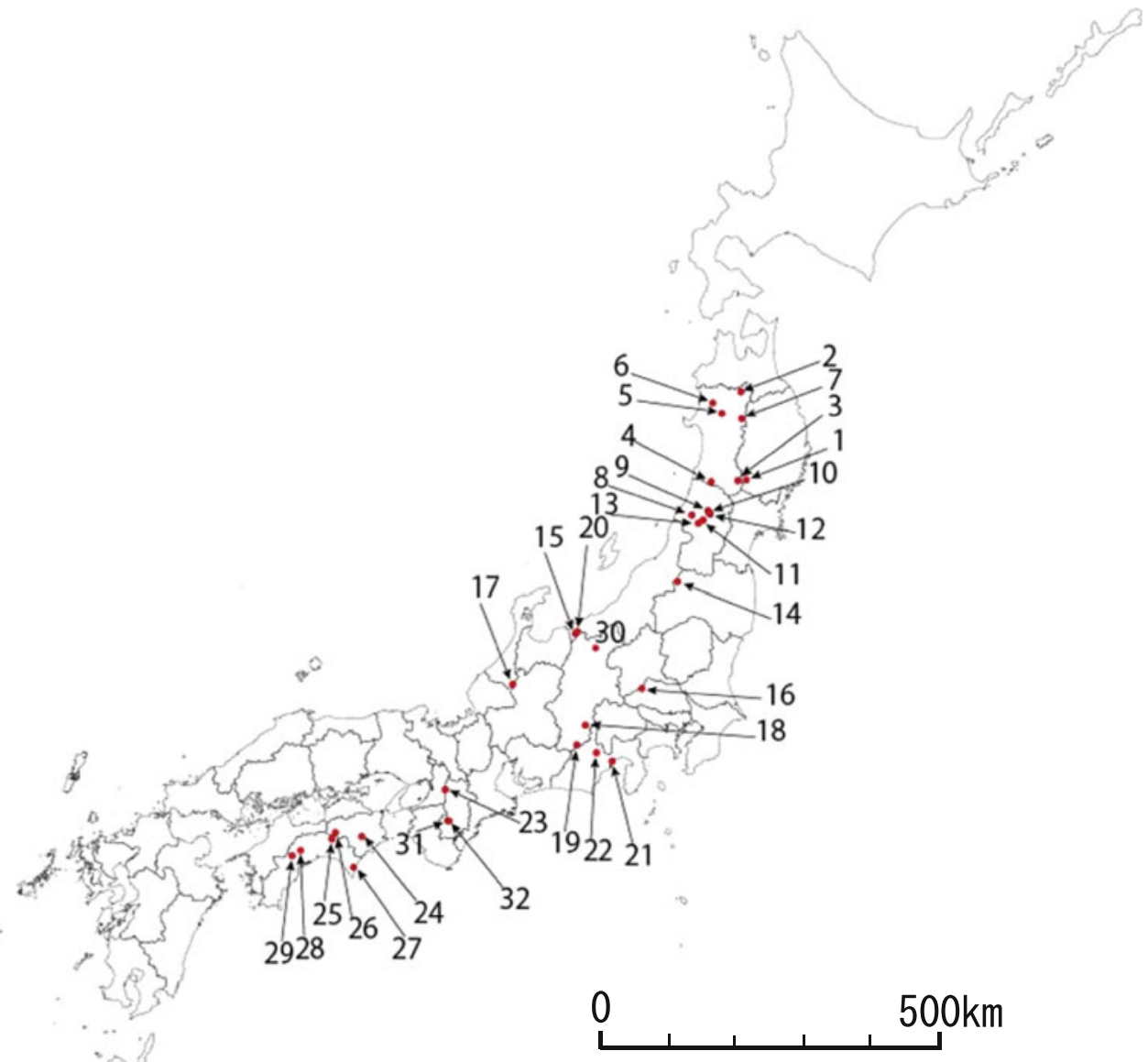


Table 1 Landslide scale based on the questionnaire results

\begin{tabular}{|c|c|c|c|c|c|c|c|c|}
\hline \multirow[t]{2}{*}{ Geologicla age } & \multirow[t]{2}{*}{ No. } & \multicolumn{7}{|c|}{ Generating area } \\
\hline & & $\mathrm{h}(\mathrm{m})$ & $\mathrm{L}(\mathrm{m})$ & rh (m) & $\theta\left(^{\circ}\right)$ & $\mathrm{t}(\mathrm{m})$ & $\mathrm{v}\left(\mathrm{m}^{3}\right)$ & $\alpha\left({ }^{\circ}\right)$ \\
\hline \multirow[t]{16}{*}{ Cenozoic era } & 1. & 250 & 450 & 130 & 14.0 & 80 & $9.0 \mathrm{E}+06$ & 7.5 \\
\hline & 2. & 240 & 200 & 90 & 28.0 & 45 & $1.0 \mathrm{E}+06$ & 31.0 \\
\hline & 3. & 950 & 1200 & 200 & 6.5 & 55 & $1.0 \mathrm{E}+07$ & 11.0 \\
\hline & 4. & 1200 & 1000 & 250 & 15.0 & 165 & $6.0 \mathrm{E}+07$ & 15.0 \\
\hline & 5. & 800 & 1100 & 230 & 12.0 & 90 & $1.5 \mathrm{E}+07$ & \\
\hline & 6. & 280 & 250 & 45 & 25.0 & 45 & $1.5 E+06$ & \\
\hline & 7. & 350 & 650 & 120 & 1.5 & 70 & $6.0 \mathrm{E}+06$ & 11.5 \\
\hline & 8. & 840 & 1140 & 150 & 8.0 & 122 & $4.9 \mathrm{E}+07$ & 4.5 \\
\hline & 9. & 470 & 750 & 100 & 13.0 & 100 & $1.0 \mathrm{E}+07$ & \\
\hline & 10. & 500 & 1000 & 50 & 6.0 & 45 & $1.3 \mathrm{E}+07$ & 4.0 \\
\hline & 11. & 500 & 750 & 70 & 6.5 & 40 & $1.0 \mathrm{E}+07$ & 5.5 \\
\hline & 12. & 2000 & 1500 & 350 & 10.5 & 150 & $8.0 \mathrm{E}+07$ & 14.0 \\
\hline & 13. & 1100 & 1200 & 190 & 8.0 & 180 & $1.0 \mathrm{E}+08$ & 2.0 \\
\hline & 14. & 1300 & 2100 & 150 & 8.5 & 140 & $4.8 \mathrm{E}+07$ & 3.5 \\
\hline & 15. & 250 & 1500 & 250 & 9.0 & 60 & $1.0 \mathrm{E}+07$ & 4.0 \\
\hline & 30. & 350 & 280 & 100 & 22.0 & 60 & $2.5 \mathrm{E}+06$ & 10.0 \\
\hline \multirow[t]{14}{*}{ Mesozoic-Paleozoic era } & 16. & 600 & 450 & 190 & 23.0 & 50 & $8.0 \mathrm{E}+06$ & 17.5 \\
\hline & 17. & 400 & 1200 & 500 & 21.0 & 130 & $2.1 \mathrm{E}+07$ & 14.0 \\
\hline & 18. & 270 & 300 & 90 & 12.5 & 30 & $1.0 \mathrm{E}+06$ & 11.0 \\
\hline & 19. & 350 & 450 & 170 & 20.0 & 48 & $5.4 \mathrm{E}+06$ & 11.0 \\
\hline & 20. & 200 & 500 & 130 & 12.5 & 60 & $6.0 \mathrm{E}+06$ & 12.0 \\
\hline & 21. & 350 & 400 & 200 & 28.0 & 65 & $3.6 \mathrm{E}+06$ & 24.5 \\
\hline & 22. & 400 & 900 & 260 & 23.0 & 60 & $2.0 \mathrm{E}+07$ & 15.0 \\
\hline & 23. & 400 & 650 & 100 & 4.0 & 70 & $9.0 \mathrm{E}+06$ & 12.5 \\
\hline & 24. & 190 & 390 & 180 & 40.0 & 30 & $7.0 \mathrm{E}+05$ & 18.0 \\
\hline & 25. & 700 & 900 & 440 & 26.5 & 65 & $1.7 \mathrm{E}+07$ & 25.0 \\
\hline & 26. & 400 & 350 & 100 & 16.5 & 35 & $2.0 \mathrm{E}+06$ & 12.0 \\
\hline & 27. & 640 & 1290 & 460 & 20.0 & 100 & $7.0 \mathrm{E}+06$ & \\
\hline & 28. & 1000 & 1050 & 450 & 20.0 & 160 & $1.0 \mathrm{E}+08$ & 13.0 \\
\hline & 29. & 400 & 1150 & 360 & 13.0 & 58 & $1.2 \mathrm{E}+07$ & 8.0 \\
\hline
\end{tabular}

Blank fields for slide surface slope indicate places for which longitudinal section views were unavailable rocks of landslides with a slope smaller than $10^{\circ}$; in contrast, for slopes $20^{\circ}$ or more, there is one reported instance in Cenozoic rocks and two in Mesozoic and Paleozoic strata (Fig. 3g).

\section{Discussion}

\section{Topography, Geology, and Scale}

From the results of the questionnaire, in 29 of the 30 examples of landslides, the volume of the moving body is
$1.0 \times 10^{6} \mathrm{~m}^{3}$ or more. Similarly, for maximum landslide thickness, all instances had a thickness of $30 \mathrm{~m}$ or more (Table 1). A volume of $1.0 \times 10^{6} \mathrm{~m}^{3}$ or larger was also treated as a large-scale landslide by Fujita (2004). These values, therefore, were regarded as a criterion for the definition of large-scale landslides by the Committee.

\section{Shape of Landslide}

From plane views of longitudinal and cross sections collected in the questionnaire, the shapes of landslide bodies in 


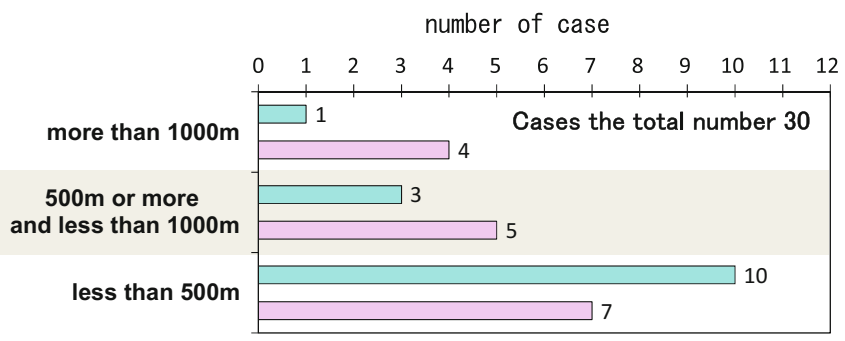

(a) Landslide maximum width

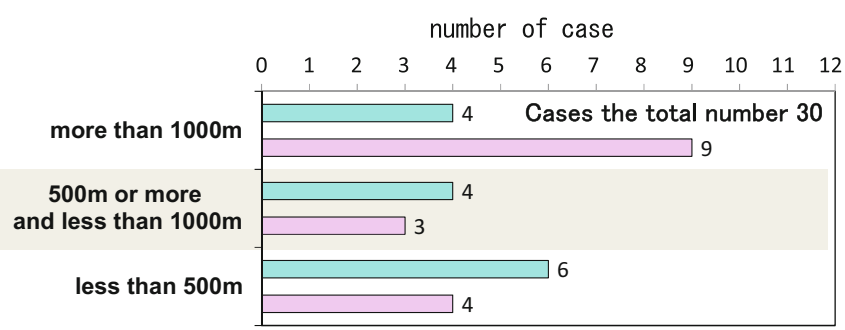

(b) Length

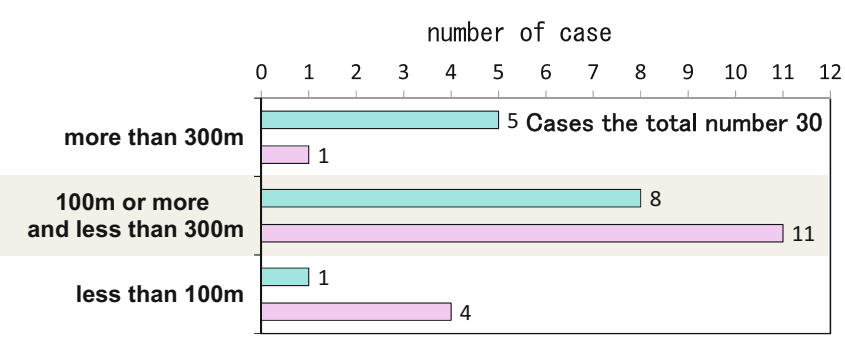

(c) Relative height

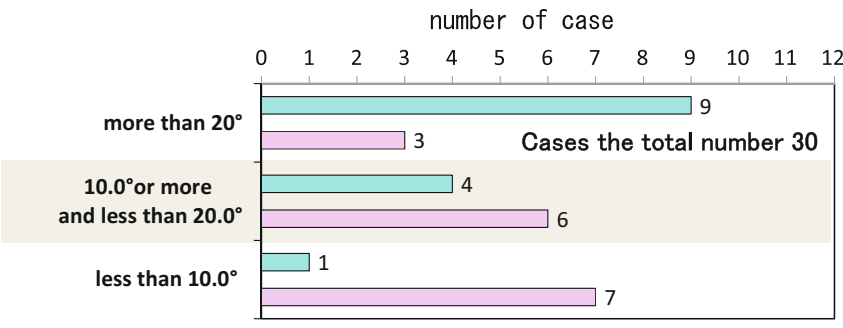

(d) Gradient of the landslide slope

Fig. 3 Landslide dimensions from the questionnaire results

terms of geology were divided into symmetric and asymmetric (Fig. 4).

For plane shapes, a straight landslide direction was considered as symmetric and a bent landslide direction as asymmetric. For longitudinal-section shapes, cases in which the gradient of landslide slope and that of the sliding surface are equal on average were considered to be symmetric; those in which the thickness of the moving body at the top of landslide is different from that at the bottom and in which the dip of sliding surface at the toe part is opposite to that of the landslide

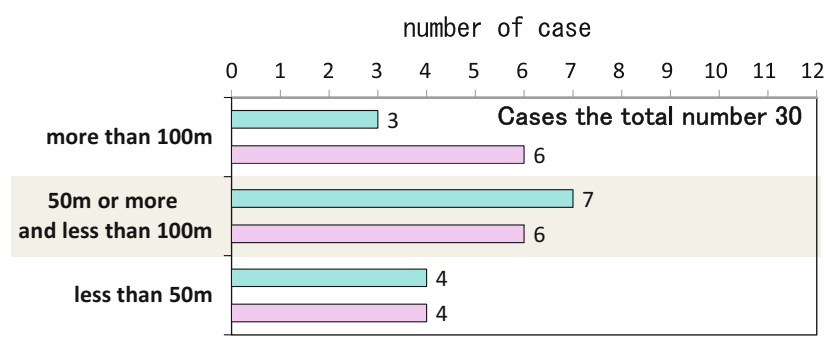

(e) Maximum thickness

number of case

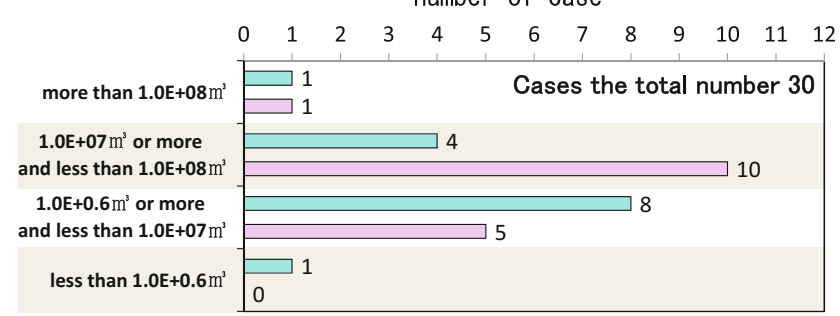

(f) Volume of the landslide

number of case

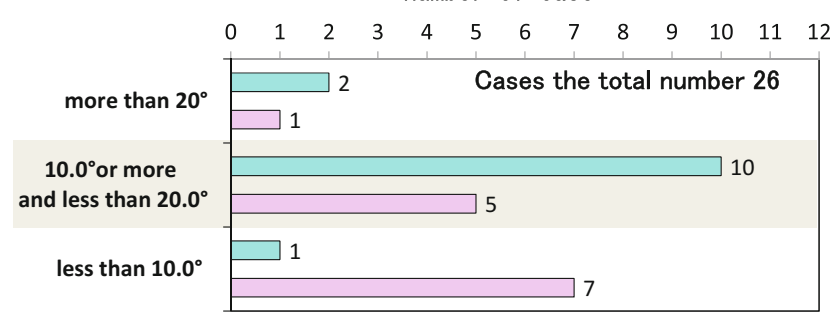

(g) Gradient of the sliding surface

Legend
$\square$ Cenozoic rocks
$\square$ Mesozoic-Paleozoic rocks

slope were regarded as asymmetric. For cross-sectional shapes, a ship-bottom shape and an isosceles-triangle shape were regarded as symmetric, and cases in which the landslide thickness slants to one side were deemed asymmetric. Landslides for which the shape was unclear were indicated by a question mark. When information became available, the section shape was added near the question mark.

For landslides in Cenozoic rocks, 11 of the 12 instances for which information is available are identified as asymmetric. Of these, 7 examples are asymmetric in planar view, 

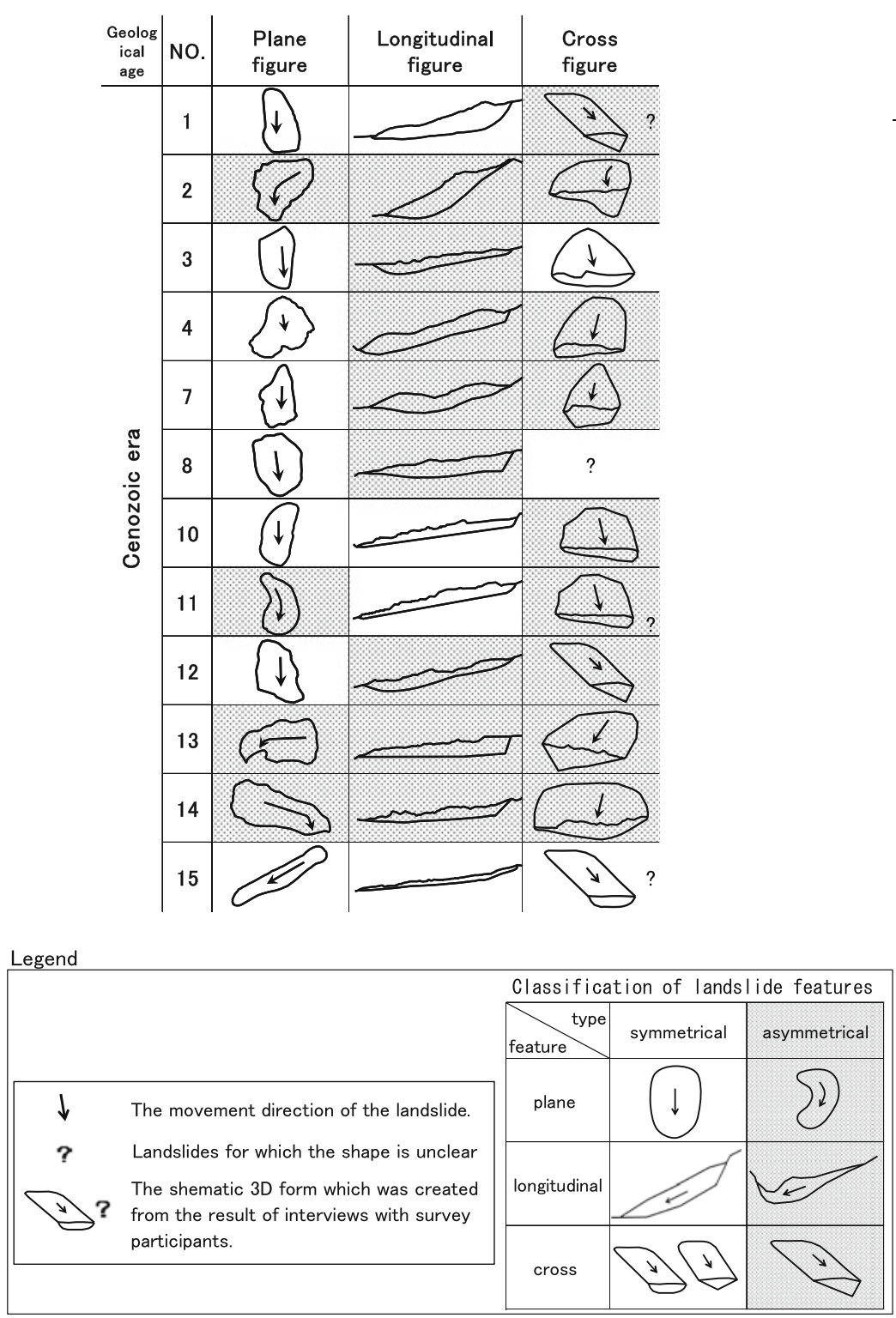

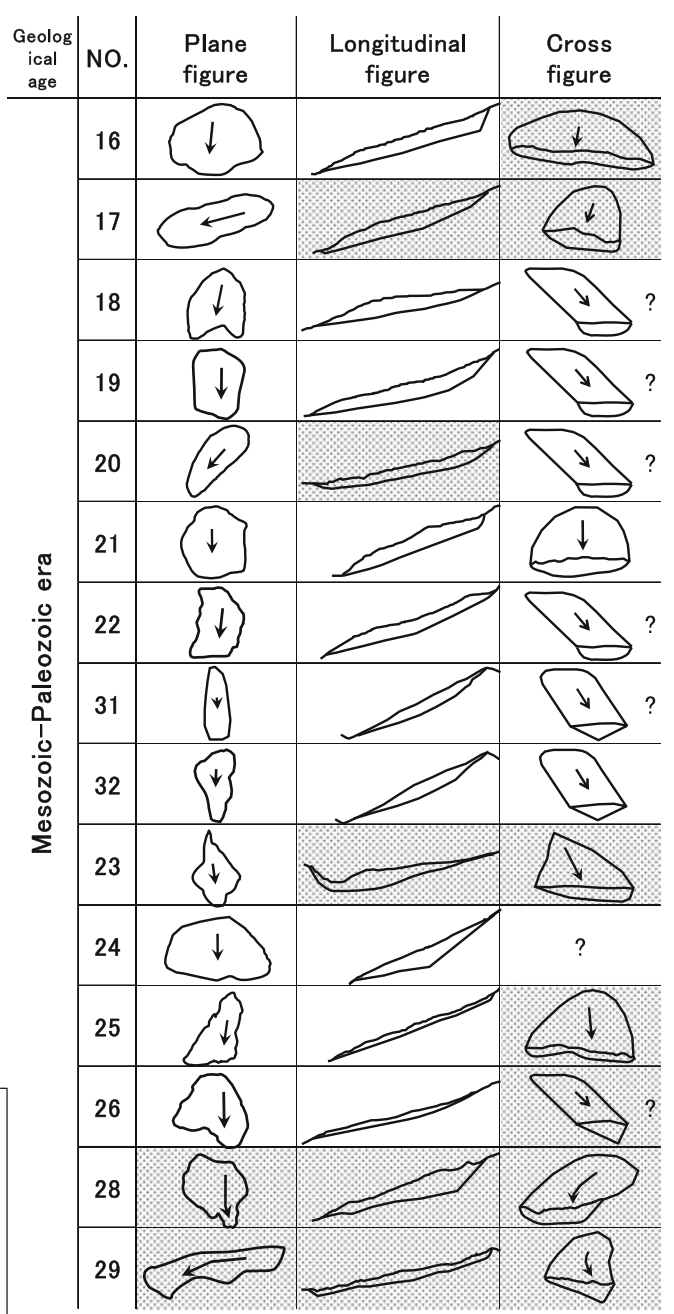

Fig. 4 Classification of landslide shape

in longitudinal section, and/or in cross-section. On the other hand, for landslides in Mesozoic and Paleozoic strata, 8 of the 15 examples are classified as asymmetric. Of these, 4 examples are asymmetric in shape, fewer than the number in Cenozoic strata.

Instances No. 7 in Cenozoic rocks and Nos. 31 and 32 in Mesozoic and Paleozoic rocks in Fig. 3 are landslides in which part or all of the landslide moving body slid downward. No. 7 is asymmetric in the longitudinal section and cross-section; Nos. 31 and 32 are symmetric in all views. Although the gradient of sliding surface of No. 2 is $31^{\circ}$, a steep slope, and the displacement over the last two years has been $1 \mathrm{~m}$, this example does not slide downward. It is suggested that a landslide with many asymmetric elements tends not to slide down easily and shows higher resistance, compared to landslides in which the planar, longitudinal section, and cross-sectional shapes are symmetric.

For example, Fig. 5 is a bird's-eye view from the northeast of the Tozawa landslide in Akita Prefecture (No.4 landslide in Table 1). It occurs in Cenozoic strata; is $1.2 \mathrm{~km}$ wide and $1.0 \mathrm{~km}$ long; has a maximum thickness of $165 \mathrm{~m}$; and the gradient of its sliding surface is $15^{\circ}$ (Table 1). This landslide is symmetrical in plan view and asymmetrical in longitudinal section and cross-section (Figs. 6 and 7). 


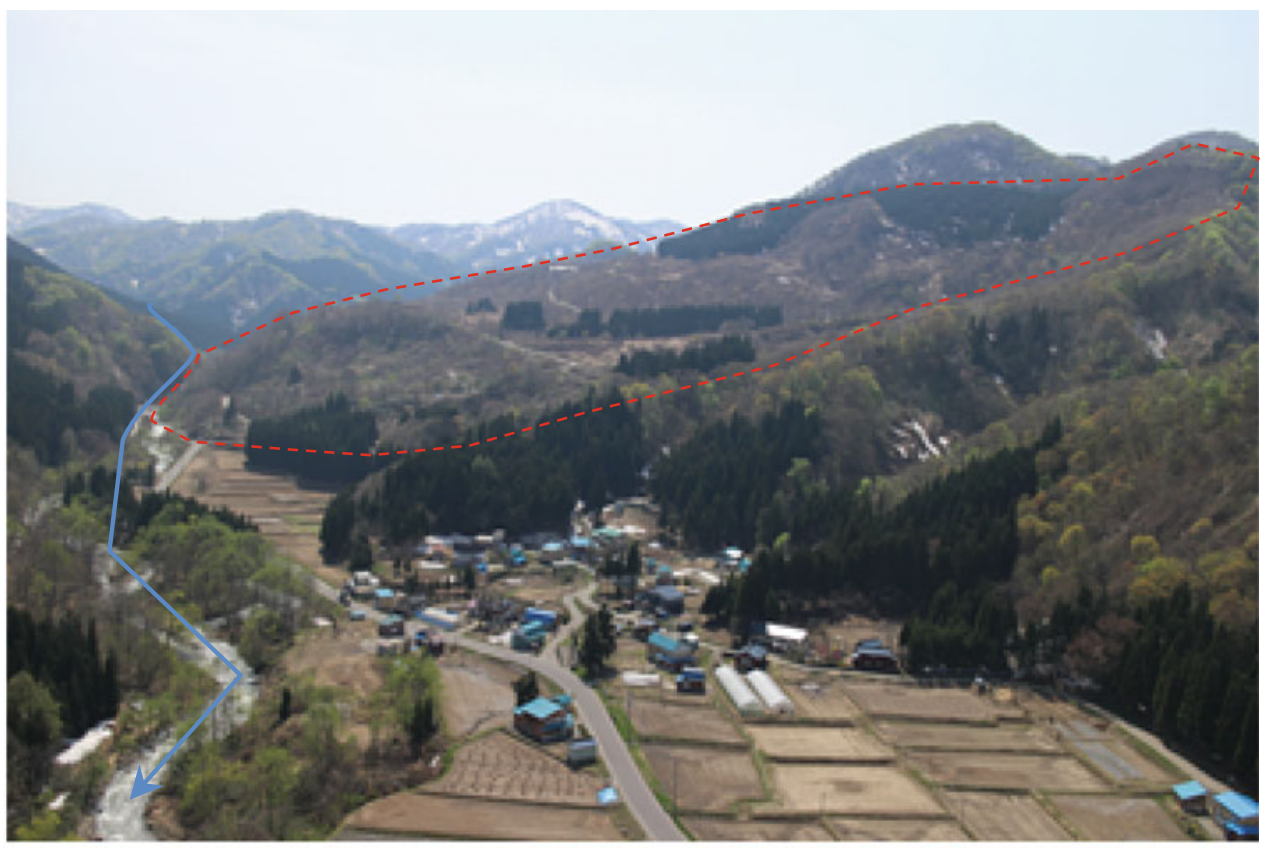

Fig. 5 Full view of the Tozawa landslide site

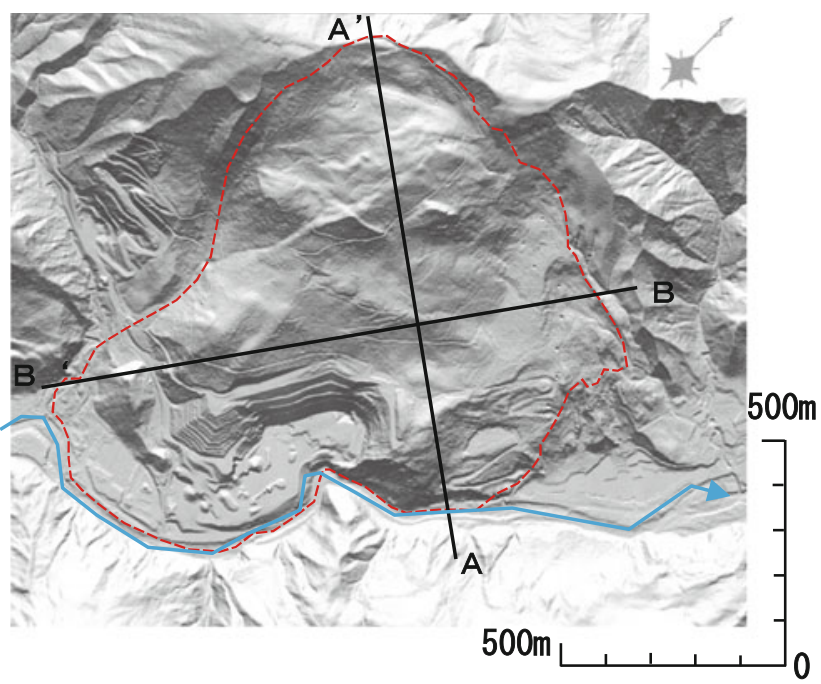

For the movement state of the Tozawa landslide, the height of the sliding cliff is approximately $20 \mathrm{~m}$, and the observed landslide movement was $0.4 \mathrm{~m} / \mathrm{year}$ for 2002-2003. The river at the bottom of the landslide is now raised, but no downward sliding movement has occurred.

As an example of a landslide in Mesozoic and Paleozoic rock, Fig. 8 shows a view of landslide No. 25 in Table 1. The landslide is $700 \mathrm{~m}$ wide and $900 \mathrm{~m}$ long, and has a maximum thickness of $65 \mathrm{~m}$ and a slide surface of $25^{\circ}$ in gradient. This landslide is symmetric in plan view and longitudinal section, but asymmetric in cross-section (Fig. 9). For the landslide, the difference in height of the sliding cliff is approximately $5 \mathrm{~m}$, the observed landslide movement rate is $3 \mathrm{~cm} /$ year for 2007-2009, and the landslide is currently not sliding.

Fig. 6 Plan view of the Tozawa landslide site

Fig. 7 Cross section of the Tozawa landslide site

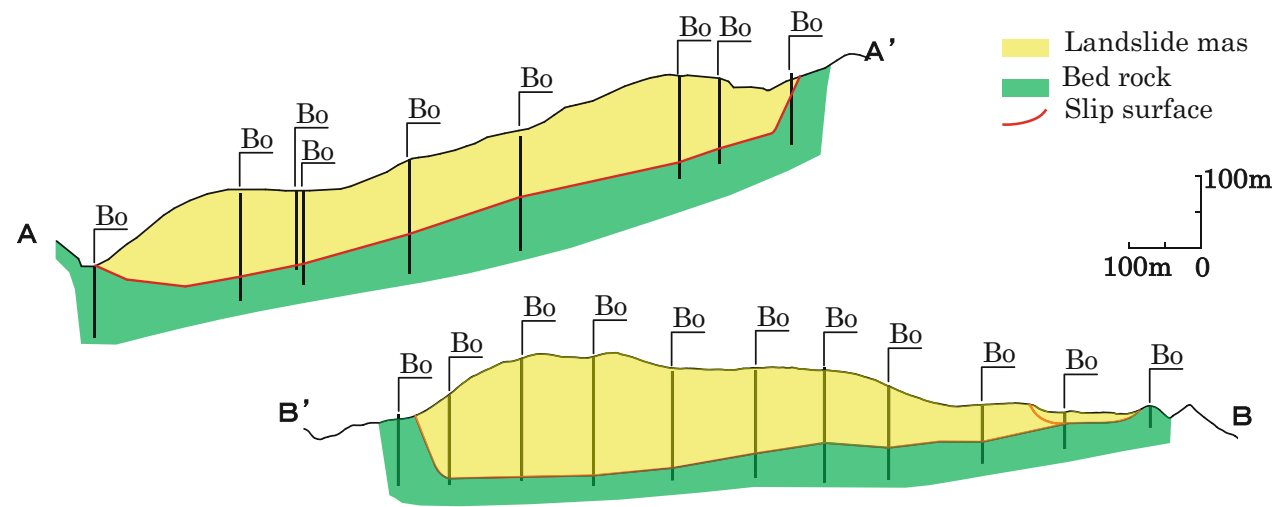


Fig. 8 Overall view of landslide No. 25

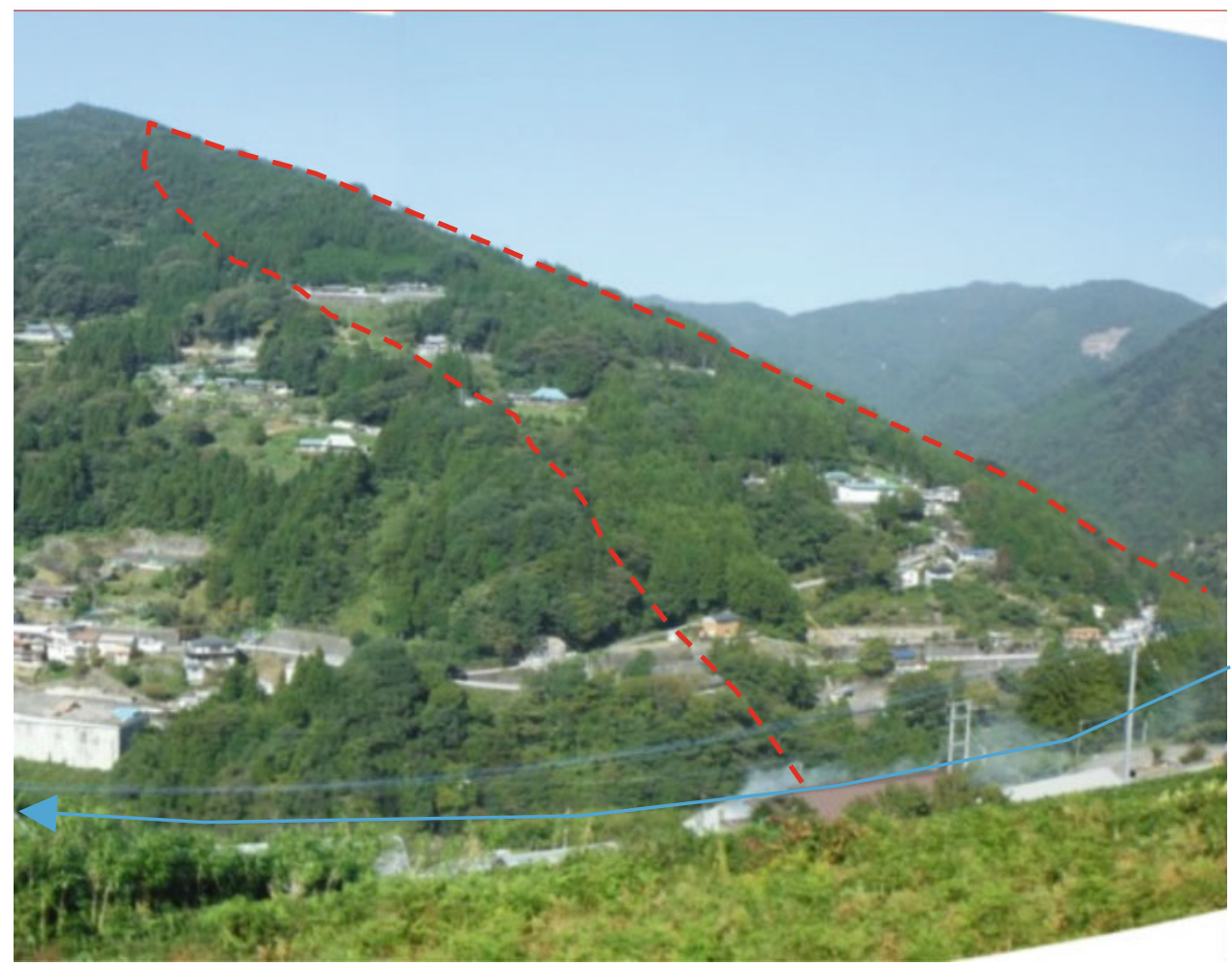

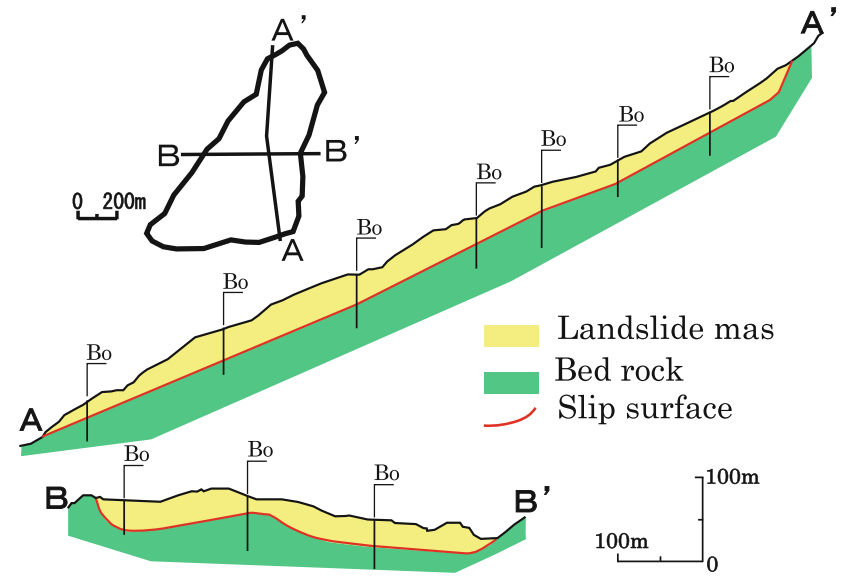

Fig. 9 Cross-section view of landslide No. 25

\section{Landslide Kinematic Structure}

\section{Time-Series Displacement of Landslide}

For some landslides, after small displacement has occurred for a certain time, the displacement velocity increases, leading to downward sliding; for others, the displacement velocity tends to increase and decrease, not leading to further sliding downward. Taking this information into consideration, landslide movement can be divided in a time-series
A

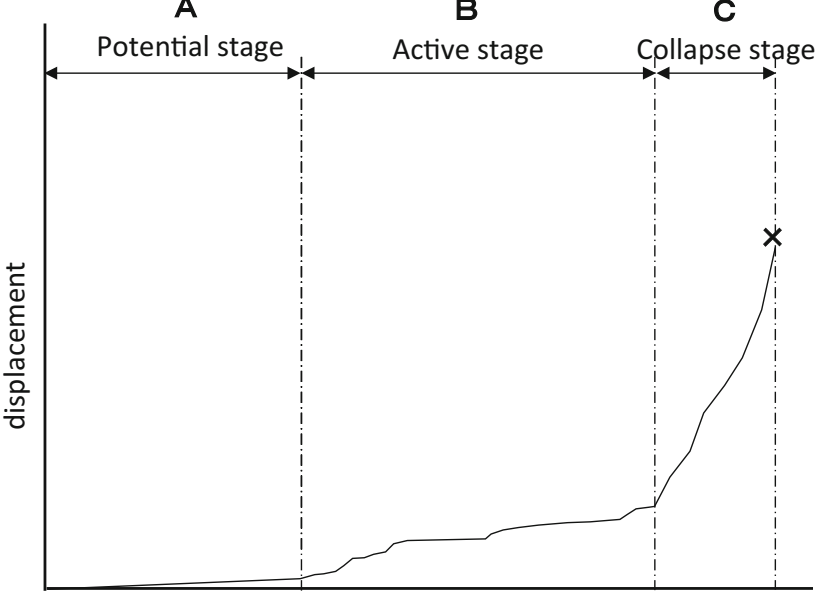

time

Fig. 10 Three stages of landslide displacement

manner into: period $\mathrm{A}$, in which small landslide displacement that can be observed with creep by monitoring equipment occurs; period $\mathrm{B}$, in which displacement that appears differently on the ground and within the structure takes place; and period $\mathrm{C}$, in which the displacement velocity increases and part or all of the moving body slides down and collapses. Herein, period A is called the potential 


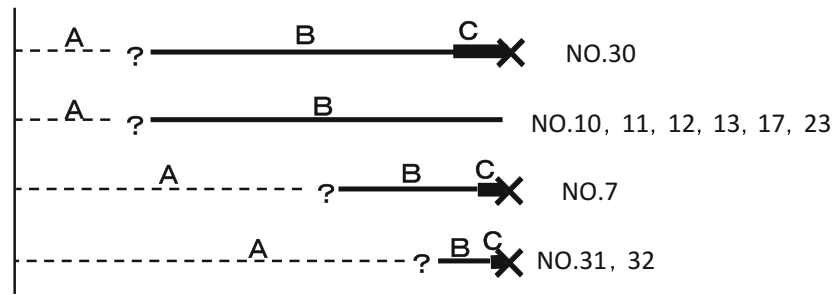

Fig. 11 Time-historical changes in the displacement stage of each landslide (A, B, C is shown in Fig. 10 No.7-32 is shown in Fig. 1)

stage of a large-scale landslide, period B is called the active stage, and period $\mathrm{C}$ is called the collapse stage (Fig. 10).

\section{Examples of Landslide Movement History}

As shown in Fig. 10, when the kinematic structure of a landslide is expressed as periods $\mathrm{A}, \mathrm{B}$, and $\mathrm{C}$, in the case of landslide No. 30 in Table 1, after a period B lasting several years period $\mathrm{C}$ commenced, and part of the moving body slid down and flowed. For landslides Nos. 10, 11, 12, 13, 17, and 23 in Table 1, displacement increases during snow-melt and heavy rain; however, as these landslides have not collapsed at present, they are in period B. For the example of landslide No. 7 in Table 1, which occurred in a volcanic region, a period B of several years was confirmed (Oyagi and Ikeda 1988). After a period $\mathrm{C}$ lasting nine days, part of the moving body collapsed and moved for $1.5 \mathrm{~km}$ as a debris avalanche (Ogawauchi et al. 1988). Landslides Nos. 31 and 32 in Fig. 1 exhibited a period $\mathrm{A}$, in which double ridges and a sliding cliff were formed, and a short period B; subsequently, sliding down and flowing out occurred (Sakurai 2013; Sakurai et al. 2013) (Fig. 11).

\section{Summary}

The results of the Committee's research can be summarized as follows

- In the questionnaire to members of the Committee, which consists of technical and research experts, details of large-scale landslides in which the volume of the moving body was $1.0 \times 10^{6} \mathrm{~m}^{3}$ or larger were obtained for 29 instances, excluding one. A large-scale landslide, therefore, is defined herein as one in which the volume of the moving body is $1.0 \times 10^{6} \mathrm{~m}^{3}$ or larger and the maximum landslide thickness is $30 \mathrm{~m}$ or larger.

- There is a trend for the relative height, gradient of landslide slope, and that of sliding surface of large-scale landslides to be smaller in Cenozoic strata than in Mesozoic and Paleozoic rocks.

- One of the factors controlling why some large-scale landslides do not slide down but displacement continues is asymmetry of shape (in any or all of plan view, longitudinal section, and cross-section) of the landslide moving body. This trend is particularly strong in landslides in Cenozoic rock. On the other hand, one of the factors causing Mesozoic and Paleozoic rock to sliding down relatively easily is that these landslides have a relatively symmetric shape.

Further analysis incorporating additional examples is required; there is a possibility that the characteristics of large-scale landslides deduced herein are also common in areas outside of Japan that have similar geology, topography, and evolution of geological structure. For large-scale landslides in which the scale of measures is apt to be large, monitoring of landslides and emergency measures suited to the characteristics of the ground of occurrence sites must be taken. It is necessary, therefore, for landslide experts to share detailed information on large-scale landslides.

\section{References}

Fujita T (2004) Scale, landslide - topography and geology knowledge and terms. Japan landslide society, land form and geology terms committee on landslide, pp 16-28 (in Japanese)

Furuya T (2003) Hazard map with landslide disaster. Geography 48 (9):25-28(in Japanese)

Furuya T, Enokida M (2004) Slope carte and description example, landslide - topography and geology knowledge and terms. Japan landslide society, land form and geology terms committee on landslide, pp 285-295 (in Japanese)

Ogawauchi Y, Yamazaki T, Yamasaki K, Kikuchi A, Obara Y, Hosaka K (1988) Occurrence mechanism of the Sumikawa landslide - result of survey on the Sumikawa landslide and outline of measures. Landslide 35(2):38-45 (in Japanese with English abstract)

Oyagi N (2004) Landslide structure - topography and geology knowledge and terms. Japan landslide society, land form and geology terms committee on landslide, pp 29-45 (in Japanese)

Oyagi N, Ikeda H (1988) Sumikawa landslide from the viewpoint of landslide structure and broad field. Landslide 35(2):1-10 (in Japanese with English abstract)

Sakurai W (2013) Measures for large-scale landslide disaster caused by typhoon No. 12 in September 2011. Kansai Branch of Japan Landslide Society, collected papers on deep layer collapse and channel blockage, pp 7-32 (in Japanese)

Sakurai W, Tokunaga H, Amino K, Kato A, Suzuki S (2013) Survey on deep layer collapse and channel blockage caused by typhoon No. 12 in 2011. Kansai branch of Japan landslide society, collected papers on deep layer collapse and channel blockage, pp 33-70 (in Japanese) 
Science and Technology Agency: National Research Institute for Earth Science and Disaster Prevention (1986) Report on disaster caused by the Jizukiyama landslide in Nagano-city on July 26, 1985, No. 26, p 45 (in Japanese)
Shinshu University Research Committee on natural disaster (1986) The Jizukiyama landslide. Japan Geotechnical Consultant Association, geology-related information Web: https://www.zenchiren.or. jp/tikei/saigai.html. Accessed 8 June 2016 (in Japanese)
Open Access This chapter is licensed under the terms of the Creative Commons Attribution 4.0 International License (http:// creativecommons.org/licenses/by/4.0/), which permits use, sharing, adaptation, distribution and reproduction in any medium or format, as long as you give appropriate credit to the original author(s) and the source, provide a link to the Creative Commons license and indicate if changes were made.
The images or other third party material in this chapter are included in the chapter's Creative Commons license, unless indicated otherwise in a credit line to the material. If material is not included in the chapter's Creative Commons license and your intended use is not permitted by statutory regulation or exceeds the permitted use, you will need to obtain permission directly from the copyright holder. 